\title{
Phylogenetic relationships between the European and Asian eight spined larch bark beetle populations (Coleoptera, Scolytidae) inferred from DNA sequences and fungal associates
}

\author{
Christian STAUFFER ${ }^{1}$, Thomas KIRISITS ${ }^{1}$, Christa NUSSBAUMER ${ }^{1 *}$, Roman PAVLIN ${ }^{1,2}$ and Michael J. \\ WINGFIELD ${ }^{3}$ \\ ${ }^{1}$ Institute of Forest Entomology, Forest Pathology \& Forest Protection, Universität für Bodenkultur, 1180-Wien, Austria;
e-mail:stauffer@ento.boku.ac.at \\ ${ }^{2}$ Biotechnical Faculty, Department of Forestry \& Renewable Forest Resources, University of Ljubljana, Slovenia \\ ${ }^{3}$ Forestry and Agricultural Biotechnology Institute, University of Pretoria, South Africa
}

Key words. Scolytidae, Ips cembrae, Ips subelongatus, phylogenetic, mtDNA, blue stain fungi

\begin{abstract}
The eight spined larch bark beetles infest various species of Larix in Europe and Asia. Ips cembrae is the only Ips species with larch as its main host. Ips subelongatus, Ips fallax, Ips shinanonensis and Ips cembrae var. engadinensis are treated as synonyms of $I$. cembrae. These three putative species and the one variety are distinguished by their host tree and geographic distribution, as it is not possible to distinguish them on the basis of morphological differences. Beetles were collected from European and Asian populations, and from hosts and geographic areas where the species were first found and described and in their natural ranges of distribution. These beetles were used to study the phylogenetic relationships of the eight spined larch bark beetles. A region of the mitochondrial gene was analysed and the blue-stain fungi associated with I. cembrae in Europe were investigated and compared with those recorded as associated with the larch bark beetle in Japan. Only minor sequence differences were detected between the populations in Europe and Asia. However, the European populations differed by $4.3 \%$ from the Asian populations. The phylogenetic analysis placed the European and Asian haplotypes in significantly distinct clusters. This distinction was supported by the finding of an insertion/deletion in a non-coding region of the mitochondrial DNA. Furthermore, there are differences in the fungi associated with the eight spined larch bark beetles in Europe and Japan. The results suggest that the $I$. cembrae complex contains at least two taxa: I. cembrae infesting larch in Europe and I. subelongatus infesting larch in Asia.
\end{abstract}

\section{INTRODUCTION}

The eight spined larch bark beetle, Ips cembrae Heer 1836 , is a secondary pest of various larch species (Larix spp.) in Europe and Asia (Schimitschek, 1930; Sawamoto, 1940; Nobuchi, 1974; Postner, 1974). The natural distribution of $I$. cembrae is central Europe, northern Russia, Siberia, Sakhalin, Korea, Mongolia, Japan and north-west China (Pfeffer, 1995). The eight spined larch bark beetle infests $L$. decidua, $L$. sibirica, $L$. kaempferi and L. gmelinii, and rarely conifers in the genera Abies, Picea and Pinus (Schimitschek, 1930; Nobuchi, 1974; Postner, 1974). According to Wood \& Bright (1992), Pfeffer (1995) and references therein, several other species of Ips are regarded as synonyms of $I$. cembrae (Table 1). These include I. subelongatus Motschulsky, 1860, I. shinanonensis Yano, 1924, I. fallax Eggers, 1915 and I. cembrae var. engadinensis Fuchs, 1913. The distributions of these beetles are listed in Table 1. Among the synonyms provided by Wood \& Bright (1992) and Pfeffer (1995) only the Asian larch bark beetle, I. subelongatus is been described to be morphologically distinct from I. cembrae (e.g. Yin et al., 1984; He et al., 1988).

I. subelongatus is the only larch bark beetle listed as a forest insect pest in China (Fuan, 1983). In Siberia, $I$. subelongatus is recorded killing healthy larch trees (Grechkin, 1962). In Europe, I. cembrae mainly infests living trees growing in regions outside the natural range of the European larch (Larix decidua), which is central Europe (Bobrov, 1972). These infestations appear to be favoured by drought and high population levels that follow after thinning and logging (Schimitschek, 1930; Crooke \& Bevan, 1957; Redfern et al., 1987). I. cembrae was introduced into Scotland presumably after the second world war (Crooke \& Bevan, 1957) and into Denmark during the last decade of this century (Harding, pers. comm.). Both introductions are likely to have originated from continental Europe.

Recently, data obtained from sequencing mitochondrial genes, in particular the cytochrome I gene (COI) have been used to resolve phylogenetic relationships in bark beetles, particularly in the genera Ips (Stauffer et al., 1997; Cognato \& Sperling, 2000), Dendroctonus (Kelley $\&$ Farell, 1998) and for determining the origin of a haplodiploid scolytid lineage (Normark et al., 1999). Furthermore, mitochondrial gene sequences are sufficiently variable to be used in the phylogeographic analyses of Dendroctonus brevicomis (Kelley et al., 1999), Ips pini (Cognato et al., 1999) and Ips typographus (Stauffer et al., 1999).

\footnotetext{
* Current Address: Institute of Legal Medicine, University of Vienna
} 
TABLE 1. Synonyms, natural distribution and host tree of Ips cembrae according to Wood \& Bright (1992) and Pfeffer (1995).

\begin{tabular}{|c|c|c|}
\hline Species (Author) & Distribution & Host \\
\hline $\begin{array}{l}\text { I. cembrae } \\
\text { (Heer, 1836) }\end{array}$ & see text & Larix decidua \\
\hline $\begin{array}{l}\text { I. cembrae var. engadiensis } \\
\text { (Fuchs, 1913) }\end{array}$ & Switzerland & Picea abies \\
\hline $\begin{array}{c}\text { I. fallax } \\
\text { (Eggers, 1915) }\end{array}$ & Russia/Mongolia & L. sibirica \\
\hline $\begin{array}{l}\text { I. subelongatus } \\
\text { (Motschulsky, 1860) }\end{array}$ & China/Japan & L. kaempferi \\
\hline $\begin{array}{l}\text { I. shinanonensis } \\
\text { (Yano, 1924) }\end{array}$ & China/Japan & L. gmelinii \\
\hline
\end{tabular}

Bark beetles vector blue-stain fungi belonging to the ascomycetous genera Ophiostoma, Ceratocystiopsis and Ceratocystis, and related anamorph genera such as Graphium and Leptographium (Wingfield et al., 1993; Paine et al., 1997). Following attack by bark beetles these fungi generally cause discolouration of sapwood. Some of these fungi are pathogenic to trees and others are thought to aid their vectors in overcoming the defence mechanisms of the host trees (Paine et. al., 1997). Most bluestain fungi are relatively specific to particular bark beetles and thus also to the host trees they infest (Upadyhay, 1981; Whitney, 1982). It is likely that this reflects a coevolutionary relationship between these fungi and their vectors. Ceratocystis laricicola is the most important fungal associate of $I$. cembrae in Scotland, where the insect has been introduced (Redfern et al., 1987). This fungus is a virulent pathogen and is thought to play a role in the death of trees infested by $I$. cembrae (Redfern et al., 1987). In Japan, several blue-stain fungi, including $C$.

TABLE 2. Countries and their abbreviations (abbr.), host trees and collectors of the larch bark beetles used in this study - see also Fig. 1.

\begin{tabular}{|c|c|c|c|}
\hline \multirow{2}{*}{\multicolumn{4}{|c|}{$\begin{array}{l}\text { Location }^{1} \\
\text { Scotland }\end{array}$}} \\
\hline & & & \\
\hline Atholl & $\mathrm{AT}$ & L. decidua & D.B. Redfern \\
\hline Denmark & & & \\
\hline Grib Skov & GS & L. decidua & S. Harding \\
\hline Germany & & & \\
\hline Postdam & PD & L. decidua & K.-H. Apel \\
\hline Hungary & & & \\
\hline Sopron & $\mathrm{SO}$ & L. decidua & F. Lakatos \\
\hline Austria & & & \\
\hline Mieders & MI & L. decidua & \\
\hline Switzerland & & & \\
\hline Chamonix & $\mathrm{CH}$ & P. abies & \\
\hline Slovenia & & & \\
\hline Peca & PE & L. decidua & \\
\hline Russia & & & \\
\hline Irkutsk & IR & L. sibirica & C. Holzschuh \\
\hline China & & & \\
\hline Heliongjiang & $\mathrm{HE}$ & L. gmelinii & A. Roques \\
\hline $\begin{array}{l}\text { Japan } \\
\text { Hokkaido }\end{array}$ & $\mathrm{HO}$ & L. kaempferi & K. Iguchi/Y. Yamaoka \\
\hline
\end{tabular}

laricicola, are associated with 1 . cembrae (Westhuizen et al., 1995; Yamaoka et al., 1998). There are no studies on the fungi associated with $I$. cembrae in continental Europe, where the insect is native.

The aim of this study was to investigate the phylogeographic relationships of European and Asian larch bark beetles of the genus Ips and to evaluate the status of the various synonyms of $I$. cembrae. This was accomplished by sequencing a COI region, and a non-coding region between COI and tRNA $A_{L E U}$ of the mitochondrial genome. Furthermore, we compare the blue stain fungi associated with $I$. cembrae in continental Europe with that of the larch bark beetle in Japan.

\section{MATERIALS AND METHODS}

\section{Insects}

Eight spined larch bark beetles were collected from areas and host trees, where individuals of the $I$. cembrae complex were first described or within their natural distribution (Table 1). Adult beetles were collected randomly from trees felled between 1995 and 1998. Beetles were collected from six populations infesting $L$. decidua in Europe, one infesting $P$. abies in Switzerland, one infesting $L$. sibirica in Russia, one infesting $L$. gmelinii in China, and one infesting L. kaempferi in Japan (Fig. 1, Table 2). Beetles were stored in absolute ethanol until required.

\section{DNA extraction, PCR amplification and sequencing}

DNA was extracted from the head and thorax of individual specimens, and the PCR procedure used was that described by Stauffer et al. (1997). A fragment was amplified using the sense primer described by Juan et al. (1995) and the antisense primer (UEA10) developed by Lunt et al. (1996). This region corresponds to position 2410 of the mitochondrial DNA of Drosophila yakuba and is situated in the second half of the COI gene. The UEA10 primer corresponds to position 3038 in the first part of the tRNA $\mathrm{LEU}_{\mathrm{LU}}$ gene of D. yakuba (Clary \& Wolstenholme, 1985). Amplified products were purified using Concert ${ }^{\mathbb{Q}}$ PCR purification columns (Life Techn.). Sequencing was performed using the UEA10 primer and the rhodamine cycle sequencing kit (Perkin Elmer) according to the manufacturer's instructions. In order to avoid PCR artefacts, each DNA sample from each individual insect was sequenced at least twice from two independent PCR amplifications.

\section{Data analysis}

Haplotype sequences were aligned using the software program CLUSTAL W 1.60 (Thompson et al., 1994) with default settings. For the maximum parsimony (MP) bootstrap analysis, the branch and bound searches of PAUP (Swofford, 1993) was used with default settings. I. typographus was used as theoutgroup. As in the phylogenetic analysis previously applied to Ips spp. (Stauffer et al., 1997), DNA sequence divergence was estimated by the gamma distance following the Tamura \& Nei (1993) model $(\alpha=0.5)$. The phenogram was constructed using the neighbour joining method (NJ) (Saitou \& Nei, 1987) and MEGA (Kumar et al., 1993).

\section{Blue-stain fungi from larch bark beetles in central Europe}

The fungi associated with $I$. cembrae were collected between 1995 and 1998, at various localities within the natural range of L. decidua in Austria. Adult insects, infested larch logs and/or bark and wood samples containing breeding galleries of $I$. cembrae were collected at the study sites Kindberg/Styria in 1995, 
TABLE 3. Polymorphic nucleotide positions of the haplotypes of the eight spined larch bark beetle from Europe and Asia. Haplotypes I-III and haplotypes IV-V differ in 20 more nucleotide sites - see text

\begin{tabular}{lccccc}
\hline & \multicolumn{5}{c}{ nucleotide position } \\
\hline \multirow{2}{*}{ Europe } & 24 & 60 & 199 & 202 & 235 \\
\cline { 2 - 6 } Haplotype I & T & A & C & C & C \\
Haplotype II & T & G & C & C & C \\
Haplotype III & A & A & C & C & C \\
Asia & & & & & \\
Haplotype IV & C & G & C & C & C \\
Haplotype V & C & G & T & T & T \\
\hline
\end{tabular}

Glein/Styria in 1997, Ehrwald/Tyrol in 1997, Hiesberg/Lower Austria in 1998, and Seetaler Alpen/Styria in 1998. Malt extract agar (MEA, $2 \%$ malt, $1.6 \%$ agar) supplemented with $100 \mathrm{mg} / 1$ streptomycin sulphate was used for cultivating fungal isolates. Occasionally, $100 \mathrm{mg} / \mathrm{l}$ of the antibiotic cycloheximide was added to the medium because it is selective for Ophiostoma spp. and their anamorphs (Harrington, 1981). Isolations were made from mature and immature beetles, larvae, pupae and from discoloured wood. In addition, isolations were made from stained bark and sapwood of larch logs, six weeks after adult I. cembrae had been inoculated into these logs, following a similar method to that described by Furniss et al. (1990) and Krokene \& Solheim (1996). In addition to isolates obtained from beetles or infected tissue, isolates were obtained by transferring ascospores and conidia from sexual (perithecia) and asexual (conidiophores) fungal structures occurring in the galleries of the insects. The Petri-dishes were incubated at room temperature and exposed to normal laboratory conditions. Pure cultures of fung were obtained by transferring mycelium, ascospores or conidial masses, from the primary isolates to fresh MEA. After the onset of sporulation the fungi were identified. Reference isolates of the fungal species were deposited in the culture collections of the Institute of Forest Entomology, Forest Pathology and Forest Protection, Universität für Bodenkultur, Vienna and of the Forestry and Agricultural Biotechnology Institute (FABI), University of Pretoria.

\section{RESULTS}

The sequences obtained for the eight spined larch bark beetles have been deposited in Genbank under the accession numbers ICU82588 (European haplotypes) and ICU82589 (Asian haplotypes). The polymorphic codon sites of COI are shown in Table 3. From seven European populations, 48 individuals were analysed. Three haplotypes that differed at a single nucleotide site were found. The sites were transitions on the third codon site, which did not affect the amino acid (AA) sequence. The seven individuals from three different Asian countries were one of two different haplotypes. These two haplotypes differed at three nucleotide sites, which were transitions on the first codon position and also did not affect the AA sequence. The Asian haplotype IV \& V differed from the European haplotype I \& III at 20 nucleotide sites in addition tothe ones shown in Table 3. Two thirds of the substitutional sites occurred at the third codon position, $29 \%$ at the first codon position and one at the second codon position, which caused an AA change.

The distribution and frequency of the five haplotypes in Eurasia is shown in Fig. 1. There is one haplotype in the Swiss and the Austrian populations, two in the Hungarian, Slovenian, German and Danish populations, and three in the Scottish population. Both continental Asian populations are made up of haplotype IV and the Japanese population, of haplotype V.

Analysis of the noncoding region between $\mathrm{COI}$ and tRNA $_{\text {LEU }}$ revealed a difference between the Asian and the European populations (Table 4). The European larch bark beetle populations could be distinguished from the Asian populations by a $7 \mathrm{bp}$ insertion/deletion. The two sequences aligned without mismatch.

The phylogenetic analysis of the sequence data revealed that the three European haplotypes and the two Asian ones are monophyletic. They reside in two distinct clades each with high bootstrap values (Fig. 2). Both, MP and NJ using the gamma distance of Tamura \& Nei (1993) model $(\alpha=0.5)$ gave the same result. The sequence divergence estimated by the gamma distance was between 4.33\% (haplotype II and IV) and 5.28\% (haplotype III and V). Within each of the clades, the sequence divergence was less than $1 \%$.

Eight fungal taxa are associated with I. cembrae in central Europe (Table 5). These include Ceratocystiopsis minuta (Siemaszko) Upadhyay \& Kendrick, an unidentified Ceratocystiopsis sp., Ceratocystis laricicola Redfern \& Minter, Ophiostoma bicolor Davidson \& Wells, $O$. brunneo-ciliatum Mathiesen-Käärik, O. piceae (Münch) H. \& P. Sydow, an unidentified Ophiostoma sp. and an

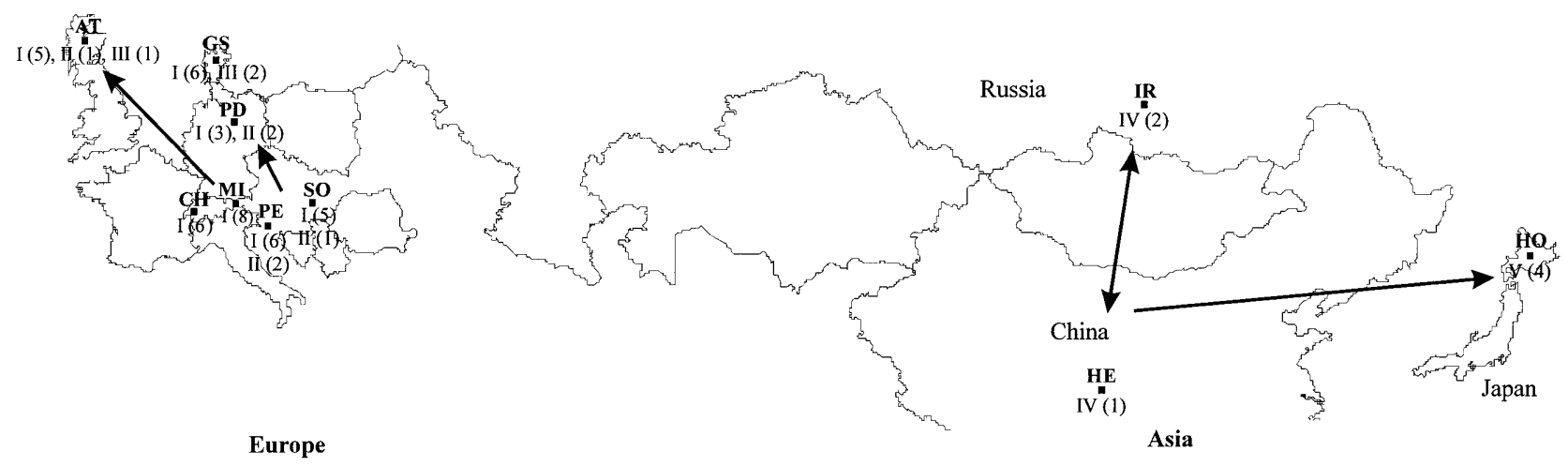

Fig. 1. Distribution of the European haplotypes. Below the abbreviations of the collection sites (see Table 2), haplotypes are given in Roman numbers (I, II, III). Number of individuals sequenced is given in parenthesis besides 


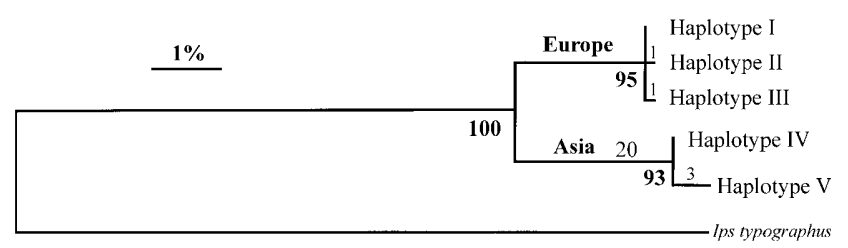

Fig. 2. The neighbour-joining (NJ) tree using the gamma distance of the Tamura and Nei (1993) model $(\alpha=0.5)$. The sister taxon I. typographus, was used as an outgroup (Stauffer et al., 1997). The maximum parsimony topology is almost identical, except that the haplotypes of each of the two main clades are not resolved. The length of the horizontal branches are proportional to the single base changes and can be read as percentage differences using the scale bar. Bootstrap percentages are indicated above the nodes for NJ.

unidentified Graphium sp. Based on frequency of occurrence, C. laricicola, O. brunneo-ciliatum and Graphium sp. are dominant in Europe, whereas $O$. bicolor and Ophiostoma sp. were only occasionally isolated.

\section{DISCUSSION}

The literature on the postglacial history of larch (Huntley \& Birks, 1983) was used to interpret the distribution of the European haplotypes. This distribution does not conform with the postglacial history of the host tree. Pollen analyses indicate that $L$. decidua was present in Poland during the last interglacial periods (Huntley \& Birks, 1983). Subsequently, there was a northward expansion of this tree across Poland during the late glacial period. About 7000 years before present, larch was restricted to the Alps. The occurrence of two or three haplotypes of the larch beetle in the northern countries of Europe, where this insect was recently introduced by man, is in contrast to the hypothesis that fewer haplotypes are found in areas of recent introduction (Hewitt, 1996). Only the larch bark beetle haplotypes I and II were found close to the glacial refugial areas (Poland \& south-west Alps). The results of this study indicate that the larch beetle might have been introduced into Scotland and Denmark from continental Europe. However, haplotype III is only recorded from Scotland and Denmark and is absent from the natural range of $I$. cembrae in continental Europe. It is unlikely that this haplotype arose independently in Scotland and Denmark or that a mutation of one nucleotide occurred shortly after its introduction. It is likely that haplotype III also occurs in central Europe, but was not detected due to the small sample size. Consequently, the origin of haplotype III requires further study. More individuals will have to be studied and more molecular markers used if we are to have a better under-

TABLE 4. Non transcribed region between COI and tRNA $A_{L E U}$, of the mitochondrial genome of the European and the Asian larch bark beetles of the genus Ips.

\begin{tabular}{|c|c|}
\hline Europe & ccataaaaga aaaaacct \\
\hline Asia & ccataaa--- ----acct \\
\hline
\end{tabular}

standing of the postglacial migration of the European larch bark beetles.

The Swiss population of $I$. cembrae, collected from Picea abies was described as I. cembrae var. engadinensis (Fuchs, 1913), which was subsequently synonymised with $I$. cembrae (e.g. Pfeffer, 1995). This population did not include any unique haplotypes and thus no host race formation can be deduced from the present data. I. cembrae can breed in logs of $P$. abies (Schimitschek, 1930; Postner, 1974) and colonises Norway spruce at higher altitudes in Austria (Kirisits, Schopf \& Lakatos, unpubl. observations).

There are no differences in the DNA sequences of the two populations of $I$. cembrae from continental Asia collected there from two different host tree species. These populations differed from the Japanese population at three nucleotide sites (Table 3 ). The substitution at nucleotide site 60 suggests that the ancestral haplotype was either haplotype II or haplotype IV. It is unlikely that this substitution occurred independently at the same site. Using rates of molecular divergence compiled by Brower (1994), specifically the median rate of 1.71 sequence divergence per million years for the COI gene in insects,

TABLE 5. Comparison of the fungal associates of the eight spined larch bark beetles in Europe and Japan. Results from Japan are those of Yamaoka et al. (1998).

\begin{tabular}{lr}
\hline & \multicolumn{1}{c}{$\begin{array}{l}\text { Blue stain fungi associated } \\
\text { with larch bark beetles from }\end{array}$} \\
\hline Europe & Ophiostoma laricis \\
\hline $\begin{array}{l}\text { Ceratocystiopsis } \text { sp. } \\
\text { Graphium } \text { sp. } \\
\text { Ophiostoma bicolor }\end{array}$ \\
\hline \multicolumn{2}{c}{ Europe \& Japan } \\
\hline \multicolumn{2}{c}{ Ceratocystiopsis minuta } \\
Ceratocystis laricicola \\
Ophiostoma brunneo-ciliatum \\
Ophiostoma sp. \\
Ophiostoma piceae \\
\hline
\end{tabular}

we estimated 2.5MYA for this migration event. The colonisation of Japan may have been by haplotype IV about $0.31 \mathrm{MYA}$ ago. This is supported by the finding that the length of the noncoding region of the European and the Asian individuals is $18 \mathrm{bp}$ and $11 \mathrm{bp}$, respectively. The two sequences aligned without mismatch, indicating that there has only been one insertion/deletion event since they diverged. This suggests that the Asian and the European larch bark beetle populations have been separated for a long time, and that they now represent distinct gene pools. A comparison of the seven species of the European Ips, revealed species-specific variability in the length of the non coding region (Stauffer, 1997). Ips mannsfeldi has the longest insertion/deletion region consisting of 57bp followed by Ips typographus with $23 \mathrm{bp}$. Ips amitinus has the shortest region with 10bp. A similar comparison of the European Ips typographus and the 
Asian Ips typographus f. japonicus revealed no differences (Stauffer, unpubl. data).

The assemblages of blue-stain fungi associated with $I$. cembrae support the DNA sequence analysis that suggests this species to consist in fact of two species, one in Europe and one in Asia. The fungi isolated in this study are similar to those previously recorded from Japanese beetles (Westhuizen et al., 1995; Yamaoka et al., 1998). There are, however, differences between the fungal assemblages associated with the two beetle populations. C. minuta, C. laricicola, O. brunneo-ciliatum, O. piceae and presmably also Ophiostoma sp., a hitherto undescribed species, that resembles $O$. europhioides (Wright \& Cain) Solheim, are associated with both European and Japanese I. cembrae (Westhuizen et al., 1995; Yamaoka et al., 1998). O. bicolor was rarely associated with European and never with Japanese beetles. Likewise, Ceratocystiopsis sp. and the Graphium sp., two important elements of the mycobiota of $I$. cembrae in Europe, are not associated with this insect in Japan (Yamaoka et al., 1998). Ophiostoma laricis, described by Westhuizen et al. (1995), was commonly associated with I. cembrae in Japan (Yamaoka et al., 1998), but not in Europe.

C. laricicola was present and is one of the most common associates of $I$. cembrae, both in Europe and Japan. This fungus is the most virulent associate of $I$. cembrae and causes lesions in the bark of L. kaempferi (Yamaoka et al., 1998) and L. decidua, (Redfern et al., 1987). Its association with I. cembrae both in Europe and Japan suggests that I. cembrae from Europe and Asia are closely related and that the association dates back to before the divergence of the insects in the two areas.

Apart from C. polonica (associated with I. typographus) and C. rufipennis (associated with Dendroctonus rufipennis), C. laricicola is the only Ceratocystis species that is consistently associated with bark beetles (Harrington \& Wingfield, 1998). This is unlike Ophiostoma spp. that are common associates of a wide range of bark beetles (Mathiesen-Käärik, 1953; Wingfield et al., 1993; Kirisits, 1996). Its high level of virulence is noteworthy and the fact that it is associated with I. cembrae in Europe and Japan is unlikely to be co-incidental. This fungus should be seen as an indication that I. cembrae in Europe and Japan are sister species.

The main aim of this study was to determine whether the European and the Asian larch bark beetles had diverged genetically and to evaluate the various names that have been used for I. cembrae. The divergence in the mitochondrial COI gene indicate that the European and the Asian larch bark beetles diverged during pleistocene. The $7 \mathrm{bp}$ insertion/deletion in the non-coding region confirms that divergence occurred long time ago and that the two clades do not share a common gene pool. This speciation is thought to be due to geographic isolation rather than to sympatric host adaptation as the same haplotypes are found on different host trees in Europe and in Asia. There are obvious differences in the composition of the blue-stain fungi associated with I. cembrae in Europe and Japan. This also supports the view that the Ips cembrae complex is composed of two distinct taxa: I. cembrae infesting larch in Europe and I. subelongatus infesting larch in Asia. Hopefully this study will stimulate the search for additional evidence for the separation. It is unlikely that a study of populations from the intermediate region (European part of Russia and western part of Siberia) would have resulted in a different conclusion as larch colonised these areas recently (Semerikov et al., 1999). It is likely that the western race of Larix sibirica is infested either with the European or the Asian form.

This finding raises the question of quarantine. There is sufficient evidence to indicate that these beetles would be a threat to larch in areas where they do not occur naturally. The introduction of $I$. cembrae into Asia or $I$. subelongatus into Europe as a result of the international trade in larch lumber could have serious consequences. The damaging consequences of introducing insects of foreign origin have already been extensively reported (Elton, 1958; Metcalf, 1995). The threat in this case is not only the beetle, but also its fungal associates. Several virulent plant pathogens are associated with bark beetles (Wingfield et al., 1993). For example, Ophiostoma ulmi (Buismann) Nannfeldt and Ophiostoma novo-ulmi Brasier are the causal agents of two pandemics of Dutch Elm Disease in this century (Brasier, 1991). Besides the highly virulent Ceratocystis laricicola, the other fungal associates of the larch bark beetles are weakly virulent-to larch, (Redfern et al., 1987; Yamaoka et al., 1998). However, pathogen/host tree interactions could be different in new environments as the hosts could be more susceptible (Brasier, 2000). Therefore, we recommend that great care should be taken to avoid the introduction of $I$. cembrae and $I$. subelongatus and their associated fungi into areas outside their natural range.

ACKNOWLEDGEMENTS. This research formed part of the Special Research Program Forest Ecosystem Restoration (SF008), funded by the Austrian Science Foundation and the Ministry of Agriculture and Forestry. Special thanks are due to A. Stradner and $\mathrm{S}$. Krumböck for their excellent technical assistance. P. Baier provided larch logs infested with I. cembrae utilised for the mycological investigations. We thank the colleagues listed in Table 2 for providing individuals of eight spined larch bark beetles and so made it possible to do this study. A. Cognato, $\mathrm{M}$. Knížek and A. Schopf made important and helpful suggestions for improving the manuscript.

\section{REFERENCES}

Bobrov E.G. 1972: History and Systematics of Larix. Nauka, Leningrad, $210 \mathrm{pp}$.

Brasier C.M. 1991: Ophiostoma novo-ulmi sp. nov., causative agent of current Dutch elm disease pandemics. Mycopathologia 115: 151-161.

Brasier C.M. 2000: The rise of the hybrid fungi. Nature (London) 405: $134 \mathrm{pp}$.

BRower A. 1994: Rapid morphological radiation and convergence among races of the butterfly Heliconus erato inferred from patterns of mitochondrial DNA evolution. Proc. Natl. Acad. Sci. U.S.A. 91: 6491-6495.

Cognato A., Seybold S.J. \& Sperling F.A.H. 1999: Incomplete barriers to mitochondrial gene flow between pheromone races 
of the North American pine engraver, Ips pini (Say) (Col., Scolytidae). Proc. R. Soc. Lond. (series B) 266: 1843-1850.

Cognato A. \& Sperling F.A.H. 2000: Phylogeny of Ips DeGeer species (Col., Scolytidae) inferred from mitochondrial cytochrome oxidase I sequence. Mol. Phylogenet. Evol. 14: 445-460.

Clary D.O. \& Wolstenholme D.R. 1985: The mitochondrial DNA molecule of Drosophila yakuba: Nucleotide sequence, gene organization, and genetic code. J. Molec. Evol. 22: 252-271

Crooke M. \& Bevan D. 1957: Note on the first British occurrence of Ips cembrae Heer (Col. Scolytidae). Forestry 30: 21-28.

EGGERS H. 1915: Ips fallax nov. spec. Entomol. Bl. 11: 96-97.

Elton C. 1958: The Ecology of Invasions by Animals and Plants. Chapman \& Hall, London, $325 \mathrm{pp}$.

FuAN Z.M. 1983: Ips subelongatus Motsch.. In Cai et al. (eds): Forest Pest Insects in China. University of Bejiing, China, pp. 444-445.

Fuchs A.G. 1913: Forstzoologische Ergebnisse einer Sommerreise ins Engadin. III. Die Arven, Lärchen und Fichtenborkenkäfer des Engadin. Naturw. Z. Land Forstw. 11: 65-86.

Furniss M.M., Solheim H. \& Christiansen E. 1990: Transmission of blue stain fungi by Ips typographus (Coleoptera: Scolytidae) in Norway spruce. Ann. Entomol. Soc. Am. 83: $712-716$.

GreChKIN V.P. 1962: Bol'shoi listvennichnyi koroed (Ips subelongatus Motsch.). Zool. Zh. 41: 552-559.

HARRINGTON T.C. 1981: Cycloheximide sensivity as a taxonomic character in Ceratocystis. Mycologia 73: 1123-1129.

HaRrington T.C. \& Wingeield M.J. 1998: The Ceratocystis species on conifers. Can. J. Bot. 76: 1446-1457.

HE L.F., Li Y.P. \& Fu W.J. 1988: Distinctive method for sexes of living Ips subelongatus (Col., Scolytidae). Contr. Shangai Inst. Entomol. 8: 73-76.

HeER O. 1836: Observationes entomologicae continentes metamorphosin Coleopterorum non nullorum adhuc incognitum. VIII. Bostrichus cembrae, pp. 28-31, Taf. V. Zürich.

HewITT G.M. 1996: Some genetic consequences of ice ages, and their role in divergence and speciation. Biol. J. Linn. Soc. $\mathbf{5 8}$ : 247-276

Huntley B. \& Birks H.J.B. 1983: An Atlas of Past and Present Pollen Maps for Europe: 0-13000 Years ago. Cambridge University Press, Cambridge, $657 \mathrm{pp}$.

Juan C., Oromi P. \& Hewitt G.M. 1995: Mitochondrial DNA phylogeny and sequential colonization of Canary Islands by darkling beetles of the genus Pimelia (Tenebrionidae). Proc. R. Soc. Lond. (Ser. B-Biol. Sci.) 261: 173-180.

Kelley S.T. \& Farell B.D. 1998: Is specialization a dead end? The phylogeny of host use in Dendroctonus bark beetles (Scolytidae). Evolution 52: 1731-1743.

Kelley S.T., Mitton J.B. \& Paine T.D. 1999: Strong differentiation in mitochondrial DNA of Dendroctonus brevicomis (Coleoptera, Scolytidae) on different subspecies of ponderosa pine. Ann. Entomol. Soc. Am. 92: 193-197.

KIRISITS T. 1996: Untersuchungen über die Vergesellschaftung von Bläuepilzen (Ophiostoma/Ceratocystis spp.) mit den den rindenbrütenden Fichtenborkenkäfern Ips typographus L., Pityogenes chalcographus L. und Hylurgops glabratus Zett. in Österreich. Diploma Thesis, Universität für Bodenkultur, Wien, $175 \mathrm{pp}$.

Krokene P. \& Solhem H. 1996: Fungal associates of five bark beetle species colonizing Norway spruce. Can. J. For. Res. 26: $2115-2122$.
Kumar S., Tamura K. \& Nei M. 1993. MEGA, Molecular Evolutionary Genetics Analysis Version 1.01. The Pennsylvania State University, PA 16802.

Lunt D., Zhang D.X., Szymura J.M. \& Hewitt G.M. 1996: The insect COI gene: Evolutionary patterns and conserved primers for phylogenetic studies. Insect Mol. Biol. 5: 153-165.

MATTHIESEN-KÄÄRIK A. 1953: Eine Übersicht über die gewöhnlichsten assozierten Bläuepilze und einige für Schweden neue Bläuepilze. Meddn. St. Skogsforsknst. 43: 1-74.

MetCALF R.L. 1995: The need for research on exotic pests in California. In Morse J.G., Metcalf R.L., Carey J.R. \& Dowell R.V. (eds): The Medfly in California: Define Critical Research. University of California, Riverside, pp. 5-39.

Motschulsky J.S. 1860: Insectes du Japon. Etudes Entomol. (Helsingfors) 9: 19-20.

NoBUchI A. 1974: Studies on Scolytidae XII: The bark beetles of the tribe Ipini in Japan (Coleoptera), Bulletin Vol. 266.

Government Forest Experiment Station, Japan, pp. 33-66.

Normark B.B., Jordal B.H. \& Farell B.D. 1999. Origin of a haplodiploid lineage. Proc. R. Soc. Lond. (series B) 266: 2253-2259.

Paine T.D., RafFa K.F. \& Harrington T.C. 1997: Interactions among scolytid bark beetles, their associated fungi and live host conifers. Annu. Rev. Entomol. 42: 179-206.

Preffer A. 1995: Zentral-und Westpaläarktische Borken- und Kernkäfer. c/o Naturhistorisches Museum Basel, Basel, 310 $\mathrm{pp}$.

POStNer M. 1974: Scolytidae (= Ipidae), Borkenkäfer. In Schwenke W. (eds.): Die Forstschädlinge Europas, Bd. 2. Parey Verlag, Berlin, pp. 334-482.

Redfern D.B., Stoakley J.T. \& Steele H. 1987: Dieback and death of larch caused by Ceratocystis laricicola sp. nov. following attack by Ips cembrae. Plant Pathology 36: 467-480.

SAITOU N. \& NEI M. 1987: The neighbour-joining method: A new method for reconstructing phylogenetic trees. Mol. Biol. Evol. 4: 406-425.

Sawamoto T. 1940: On the larch bark beetles of Sakhalin, Hokkaido, and Honshu. Insecta Matsumurana 14: 95-107.

ScHIMTSCHEK E. 1930: Der achtzähnige Lärchenborkenkäfer Ips cembrae Heer - Zur Kenntnis seiner Biologie und Ökologie sowie seines Lebensvereines. J. Appl. Entomol. 27: 253-344.

Semerirov V.L., Semerizov L.F. \& Lascoux M. 1999: Intra- and interspecific allozyme variability in Eurasian Larix Mill. species. Heredity 82: 293-204.

StaUfFer C. 1997: A molecular method to determine sibling species within the genus Ips. In Grégoire J.C., Liebhold A.M., Stephen F.M., Day K.R. \& Salom S.M. (eds): Integrating Cultural Tactics into the Management of Bark Beetles and Reforestation Pests. USDA Forest Service General Technical Report, Randor, PA, pp. 87-91.

Stauffer C., Lakatos F. \& Hewitt G. 1997: Phylogenetic relationships of the bark beetle species of the genus Ips de Geer. Insect Mol. Biol. 6: 233-240.

Stauffer C., Lakatos F. \& Hewitt G. 1999. Phylogeography and postglacial colonization routes of Ips typographus (Coleoptera, Scolytidae). Mol. Ecol. 8: 763-773.

SwOFFord D.L. 1993: Phylogenetic Analysis Using Parsimony (PAUP), Version 3.1.1. Illinois Natural History Survey, Champaign.

TAMURA K. \& NEI M. 1993: Estimation of the number of nucleotide substitutions in the control region of the mitochondrial DNA in humans and chimpanzees. Mol. Biol. Evol. 10: 512-526. 
Thompson J.D., Higgins D.G. \& Gibson T.J. 1994: CLUSTAL W: Improving the sensitivity of progressive multiple sequence alignment through sequence weighting, position specific gap penalties and weight matrix choice. Nucleic Acids Res. 22: $4672 \mathrm{pp}$.

UpadHYAY H.P. 1981: A Monograph of Ceratocystis and Ceratocystiopsis. Universtiy of Georgia Press, Athens, Georgia, 176 pp.

Westhutzen K. van der, Wingfield M.J., Yamaoka Y., Kemp G.H.J. \& Crous P.W. 1995: A new species of Ophiostoma with a Leptographium anamorph from larch in Japan. Mycol. Res. 99: 1334-1338.

WHITNEY H.S. 1982: Relationships between bark beetles and symbiotic organisms. In Mitton J.B. \& Sturgeon K.B. (eds) Bark Beetles in North America Conifers, Univ. Texas Press, Austin, 539 pp.
Wingfield M.J., SeIFert K.A. \& Webber J.F. 1993: Ceratocystis and Ophiostoma - Taxonomy, Ecology and Pathogenicity. American Phytopathological Society, St. Paul, Minnesota, 293 pp.

Woon S.L. \& BRIGHT D.E. 1992: A catalog of Scolytidae and Platypodidae (Coleoptera), Part 2: Taxonomic Index Vol. A. Great Basin Naturalist Memoirs, No 13, Brigham Young University, US, $833 \mathrm{pp}$.

Yamaoka Y., Wingeield M.J., Ohsawa M. \& Kuroda Y. 1998: Ophiostomatoid fungi associated with Ips cembrae in Japan and their pathogenicity to Japanese larch. Mycoscience 39: 367-378.

Yano S. 1924: Karamatsu no Senkochu ni Kansuru Chosa. Tokyo Regional Forest Office, Tokyo, 23 pp.

YIN H.F., HUANG F.C. \& Li Z.L. 1984: Ips subelongatus Motsch. Econ. Insect Fuan of China Fasc. 29: 128-129.

Received February 17, 2000; accepted June 26, 2000 